\title{
PENGARUH MOTIVASI,PELATIHAN DAN GAJI TERHADAP KINERJA KARYAWAN TETAP PADA UNIVERSITAS BORNEO TARAKAN
}

\author{
THE EFFECT OF MOTIVATION, TRAINING AND SALARY \\ ON PERMANENT PERFORMANCE OF EMPLOYEES IN \\ BOERNEO TARAKAN UNIVERSITY
}

\author{
Jeni Mandua $^{1)}$, Syahran ${ }^{2)}$ \\ (Universitas Borneo Tarakan) \\ Email: jenimandua@yahoo.co.id, \\ syahran_007@yahoo.com
}

\begin{abstract}
Abstrak: Penelitian ini bertujuan untuk menguji pengaruh motivasi, pelatihan dan gaji terhadap kinerja karyawan tetap pada Universitas Borneo Tarakan. Pada penelitian ini menggunakan pendekatan kuantitatif dengan metode survei yang menggunakan pertanyaan tertulis. Penarikan sampel dalam penelitian ini menggunakan metode slovin. Sampel dalam penelitian ini adalah karyawan tetap pada Universitas Borneo Tarakan. Jumlah responden sebanyak 61 karyawan. Metode analisis menggunakan alat analisis dengan bantuan program SPSS Versi 16.0. Hasil penelitian ini menunjukkan bahwa motivasi berpengaruh positif terhadap kineja dengan nilai t-hitung > t-tabel, sebesar 1.845 dan nilai tingkat signifikan 1.670, pelatihan berpengaruh negatifi terhadap kinerja dan tidak signifikan dengan nilai t-hitung < t-table, sebesar 666 dan nilai tingkat signifikan sebesar 1.670 dan gaji berpengaruh negatifi terhadap kinerja dan tidak signifikan dengan nilai thitung $<$ t-table sebesar 406 dan nilai tingkat signifikan sebesar 1.670 .
\end{abstract}

Kata Kunci: Motivasi, Pelatihan, Gaji, Kinerja

Abstract: This study aims to examine the effect of motivation, training and salary on employee performance at the University of Borneo Tarakan. In this study using a quantitative approach with a survey method that uses written questions. Sampling in this study uses Slovin method. The sample in this study were permanent employees at the University of Borneo Tarakan. The number of respondents was 61 employees. The analytical method uses an analytical tool with the help of the SPSS Version 16.0 program. The results of this study indicate that motivation has a positive effect on performance with t-count $>$ t-table, 1,845 and significant level 1,670, training has a negative effect on performance and is not significant with tcount $<t$-table, 666 and value significant level of 1,670 and salary has a negative effect on performance and is not significant with t-count $<$ t-table of 406 and significant level of 1,670.

Keywords: Motivation, Training, Salary, Performance

\section{LATAR BELAKANG}

Sumber daya manusia merupakan aspek yang penting bagi keberlangsungan hidup dan perkembangan organisasi. Sumber daya manusia berguna dalam penguasaan teknologi, menggunakan modal, mengatur dana, dan menghasilkan produk yang berkualitas. Seberapa canggih teknologi yang dimanfaatkan oleh organisasi dalam menjalankan pekerjaan sangat ditentukan Sumber daya manusia yang berkualitas adalah sumber daya manusia yang memiliki pengetahuan, kemampuan, keterampilan dan sikap yang baik dalam bekerja. Oleh karena itu, organisasi perlu mengambil langkah 
agar dapat mengembangkan dan meningkatkan kualitas karyawan. Karyawan diharapkan selalu mengasah pengetahuan, keterampilan dan kemampuan agar lebih baik serta dapat meningkatkan kinerja karyawan dalam organisasi tersebut,

oleh kualitas sumber daya manusia yang mengoperasikannya (Rezita, 2015).

Perguruan tinggi merupakan salah satu subsistem pendidikan nasional yang tidak dapat dipisahkan dari subsistem lainnya baik di dalam maupun diluar sistem pendidikan. Keberadaan perguruan tinggi dalam keseluruhan kehidupan berbangsa dan bernegara, mempunyai peran yang amat besar melalui tri dharma perguruan tinggi yaitu pendidikan, penelitian dan pengabdian kepada masyarakat. Dalam Undang-Undang nomor 20 tahun 2003 tentang Sistem Pendidikan Nasional dikatakan bahwa Perguruan Tinggi berkewajiban menyelenggarakan pendidikan, penelitian dan pengabdian kepada masyarakat (pasal 20 ayat 2). Perguruan tinggi memiliki kegiatan pendidikan terarah, sesuai dengan keinginan dan kebutuhan pembangunan, maka penyelenggaraan perguruan tinggi merupakan salah satu lembaga pendidikan yang secara formal diserahi tugas dan tanggung jawab mempersiapkan mahasiswa sesuai dengan tujuan pendidikan nasional, yaitu mengisi kebutuhan masyarakat akan tersedianya tenaga ahli dan tenaga terampil dengan tingkat dan jenis kemampuan yang sangat beragam. Selain itu penyelenggara pendidikan berkewajiban menyediakan lulusan bukan saja dalam jumlah yang besar dan banyak, tetapi juga berkualitas dan disiplin tinggi, serta mampu menjadi motivator dan penggerak pembangunan.

Faktor yang mendukung kinerja karyawan yaitu faktor internal dan faktor eksternal. Faktor internal ditimbulkan oleh dorongan yang muncul dari diri para pekerja itu sendiri, seperti memberikan motivasi kerja. Sementara faktor eksternal ditimbulkan oleh dorongan dari luar diri mereka sendiri. Karyawan yang memiliki kualitas kehidupan kerja (quality work life) (Santika, 2011) yang menunjukkan bahwa komponen kualitas kehidupan kerja (quality work life) mempunyai hubungan dan pengaruh yang positif terhadap motivasi kerja. Pelatihan atau training merupakan suatu kegiatan yang bermaksud untuk memperbaiki dan mengembangkan sikap, tingkah laku, keterampilan, dan pengetahuan karyawan untuk sesuai dengan keinginan organisasi, dengan demikian pelatihan yang dimaksud adalah dalam pengertian yang luas, tidak terbatas hanya untuk mengembangkan berbagai ketrampilan semata (Musafir, 2009). Pemberian gaji juga dapat mempengaruhi kinerja karyawam, Kinerja yang bagus dan tenaga kerja yang handal erat kaitannya dengan gaji yang pada dasarnya timbul akibat adanya tujuan untuk meningkatkan perusahaan yang lebih besar. Oleh karena itu, perusahaan juga harus memperhatikan prinsip keadilan dalam memberikan gaji kepada karyawannya.

\section{RUMUSAN MASALAH}

1. Apakah motivasi berpengaruh terhadap kinerja karyawan tetap pada Universsitas Borneo Tarakan?

2. Apakah pelatiahan berpengaruh terhadap kinerja karyawan tetap pada Universitas Borneo Tarakan?

3. Apakah gaji berpengaruh terhadap kinerja karyawan tetap pada Universitas Borneo Tarakan?

\section{TUJUAN PENELITIAN}

1. Untuk mengatahui pengaruh motivasi terhadap kinerja karyawan tetap pada Universitas Borneo Tarakan.

2. Untuk mengetahui pengaruh pelatihan terhadap kinerja karyawan tetap pada Universitas Borneo Tarakan.

3. Untuk mengetahui pengaruh gaji terhadap kinerja karyawan tetap pada Universitas Borneo Tarakan. 


\section{TINJAUAN PUSTAKA}

\section{$\underline{\text { Motivasi }}$}

Rivai (2009) mendefinisikan motivasi adalah serangkaian sikap dan nilai-nilai yang mempengaruhi individu untuk mencapai hal yang spesifik sesuai dengan tujuan individu, sikap dan nilai merupakan suatu yang invinsible yang memberi kekuatan untuk mendorong individu bertingkah laku dalam mencapai tujuan. Motivasi berasal dari kata latin movere yang berarti dorongan, keinginan, sebab, atau alasan seseorang melakukan sesuatu. Malthis (2006), motivasi adalah keinginan dalam diri seseorang yang menyebabkan orang tersebut bertindak.

\section{Pelatihan}

Kaswan (2012), pelatihan adalah proses meningkatkan pengetahuan yang meliputi pengubahan sikap sehingga karyawan dapat melakukan pekerjaannya lebih efektif. Simamora (2004) mendefinisikan pelatihan karyawan atau training adalah upaya sistematik perusahaan untuk meningkatkan segenap pengetahuan (knowledge), ketrampilan (skill) dan sikap-sikap kerja (attitudes) para karyawan melalui proses belajar agar optimal dalam menjalankan fungsi dan tugas-tugas jabatannya. Menurut Mondy (2008), pelatihan dan pengembangan (training and development) adalah jantung dari upaya berkelanjutan untuk meningkatkan kompetensi karyawan dan kinerja organisasi. Sedangkan menurut Dessler (2010), Pelatihan adalah proses mengajar keterampilan yang dibutuhkan karyawan baru untuk melakukan pekerjaannya. Pelatihan merupakan proses yang dibutuhkan untuk meningkatkan pengetahuan, kemampuan, dan ketrampilan seseorang terhadap pekerjaannya. Penyelenggaran training merupakan salah satu usaha-usaha yang dilakukan suatu perusahaan dalam mengembangkan sumber daya manusia untuk mengantisipasi adanya perubahanperubahan yang tidak dapat diprediksi sebelumnya.

$\underline{\text { Gaji }}$

Menurut Andrew E. Sikula (2011) mendefinisikan Gaji adalah balas jasa dalam bentuk uang yang diterima karyawan sebagai konsekuensi dari statusnya sebagai seorang karyawan yang memberikan kontribusi dalam mencapai tujuan perusahaan. Menurut Hasibuan (2007) gaji adalah balas jasa yang dibayar secara periodik kepada karyawan tetap serta mempunyai jaminan yang pasti. Menurut Samsudin (2010) gaji adalah sesuatu yang berkaitan dengan uang yang diberikan kepada pegawai atau karyawan. Menurut Rivai (2009) mendefinisikan gaji merupakan balas jasa dalam bentuk uang yang diterima karyawan sebagai konsekuensi dari kedudukan sebagai karyawan yang memberikan sumbangan dan pikiran dalam mencapai tujuan perusahaan.

\section{Kinerja Karyawan}

Menurut Wirawan

(2009) mendefinisikan bahwa kinerja merupakan singkatan dari kinetika energi kerja yang padanannya dalam Bahasa Inggris adalah performance. Kinerja adalah keluaran yang dihasilkan oleh fungsi-fungsi atau indikatorindikator suatu pekerjaan atau suatu profesi dalam waktu tertentu. Kinerja adalah hasil kerja secara kualitas dan kuantitas yang dicapai oleh seorang karyawan dalam melaksanakan tugasnya sesuai dengan tanggung jawab yang diberikan kepadanya (Mangkunegara, 2011). Berdasarkan Simamora (2004), kinerja adalah pencapaian tugas-tugas yang membentuk pekerjaan karyawan dan merefleksikan seberapa baik karyawan memenuhi persyaratan sebuah pekerjaan. Sedangkan Mathis dan Jackson (2006) menjelaskan bahwa kinerja adalah apa yang dilakukan atau tidak dilakukan oleh 
karyawan. Selain itu Mathis dan Jackson (2006) menjelaskan ada tiga faktor utama yang mempengaruhi kinerja karyawan adalah kemampuan individu untuk melakukan pekerjaan tersebut, tingkat usaha yang dicurahkan dan dukungan organisasi yang diterimanya.

\section{$\underline{\text { Hipotesis }}$}

Hipotesis 1:

Motivasi kerja berpengaruh positif terhadap kinerja karyawan.

Hipotesis2 :

Pelatihan berpengaruh positif terhadap kinerja karyawan.

Hipotesis3 :

Gaji berpengaruh positif terhadap kinerja karyawan

\section{$\underline{\text { Kerangka Penelitian }}$}

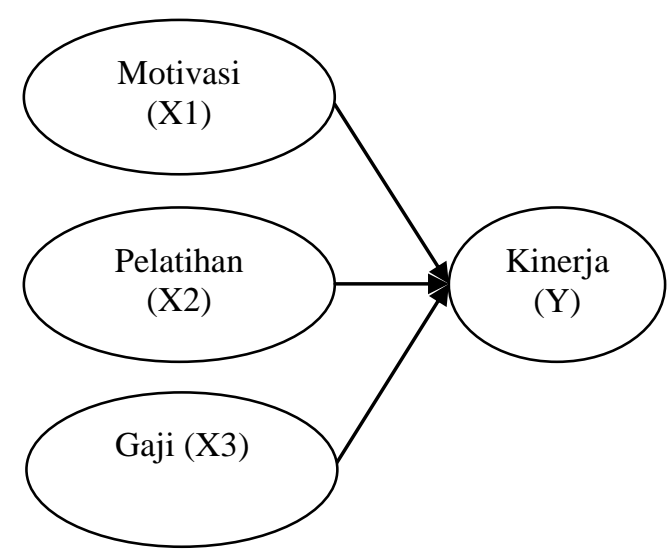

\section{METODE PENELITIAN}

\section{Desain Penelitian}

Desain penelitian merupakan model atau metode yang digunakan peneliti untuk melakukan suatu penelitian yang memberikan arah terhadap jalannya penelitian.

Penelitian ini menggunakan pendekatan kuantitatif dengan metode survei. Metode survei merupakan metode pengumpulan data primer yang menggunakan pertanyaan lisan dan tertulis (Etta dan Sopiah, 2010). Penelitian kuantitatif adalah penelitian yang membutuhkan penggunaa struktur pertanyaan dimana pilihan-pilihan jawabannya telah disediakan dan membutuhkan banyak responden (Mangkunegara,2011).

\section{$\underline{\text { Populasi dan Sampel }}$}

Populasi adalah gabungan dari seluruh elemen yang terbentuk peristiwa, hal, atau orang yang memiliki karakteristik serupa yang menjadi pusat perhatian peneliti, karena dipandang sebagai semesta penelitian (Ferdinand, 2006). Sampel adalah sebagian atau wakil populasi yang diteliti (Arikunto, 2006). Teknik pengambilan sampel yaitu responden yang akan di jadikan sebagai sampel dalam penelitian ini mencakup pada jumlah populasi yang telah ditentukan. Dalam Penelitian Ini penulis mempersempit sampel adalah jumlah seluruh karyawan dengan menghitung sampel yang dilakukan dengan menggunakan metode slovin menurut Sugiyono (2011). Populasi yang terdapat dalam penelitian ini berjumlah 159 karyawan dan presisi yang ditetapkan $10 \%$. Maka besar sampel pada penelitian ini adalah 61 karyawan.

\section{Data Penelitian}

\section{Jenis dan Sumber Data}

Jenis data yang digunakan dalam penelitian ini menurut Sunyoto (2013) adalah:

\section{Data Primer}

Data primer adalah data yang diperoleh langsung dari responden (objek penelitian). Data primer dalam penelitian ini diperoleh dengan memberikan angket (kuesioner) yang meliputi angket tentang pengaruh pengembangan karier dan penilaian prestasi kerja terhadap terhadap kinerja karyawan pada Universitas Borneo Tarakan.

2. Data Sekunder

Data sekunder adalah data yang diperoleh melalui data yang telah diteliti 
dan dikumpulkan oleh pihak lain yang berkaitan dengan permasalahan penelitian. Data sekunder yang diperoleh dari berbagai bahan pustaka, baik berupa buku, jurnal-jurnal dan dokumen lainnya yang ada hubungannya dengan materi kajian.

\section{$\underline{\text { Teknik Pengumpulan Data }}$}

Data primer pada penelitian dikumpulkan melalui kuesioner yang dibagikan kepada responden, yangberbentuk daftar pertanyaan untuk diisi dengan jawaban yang disediakan. Menurut Sugiyono (2012) kuesioner adalah pengumpulan data yang dilakukan dengan cara memberi seperangkat pertanyaan atau pernyataan tertulis kepada responden untuk dijawabnya.

Variabel Penelitian dan Definisi

Konseptual

Definisi Konseptual

Definisi konseptual berdasarkan Soedjaji (2000) merupakan ide abstrak yang dapat digunakan untuk mengadakan klasifikasi atau penggolongan yang pada umumnya dinyatakan dengan suatu istilah atau rangkaian kata.

\section{Metode Analisi Data}

Analisis data dapat diartikan memperkirakan besarnya pengaruh secara kuantitatif dari perubahan suatu (beberapa) kejadian terhadap sesuatu (beberapa) kejadian lainnya, serta memeperkirakan atau meramalkan kejadian lainnya dapat dinyatakan dengan perubahan nilai variabel (Hasan, 2003). Adapun metode analisis data yang digunakan dalam penelitian ini terdiri dari Uji Validitas, Uji Reliabilitas dan uji hipotesis. Berikut diuraikan metode analisis data dalam penelitian ini.
Uji Validitas dan Reliabilitas

$\underline{\text { Validitas }}$

Menurut Ghozali (2006) uji validitas adalah suatu uji yang digunakan untuk mengukur sah atau tidaknya suatu kuesioner. Pada uji validitas dilakukan untuk meyakinkan bahwa hasil pengukur sesuai dengan apa yang ingin kita ukur. Item-item yang mengukur konsep yang sama akan memiliki korelasi yang tinggi dan berkorelasi rendah dengan item-item yang mengukur konsep yang berbeda (Sekaran, 2006).

\section{$\underline{\text { Reliabilitas }}$}

Menurut Ghozali (2006) reliabilitas sebenarnya adalah alat untuk mengukur suatu kuesioner yang merupakan indikator dari variabel atau konstruk. Pengukuran reliabilitas dapat dilakukan dengan uji statistik Cronbach Alpha ( $\alpha)$. Suatu konstruk atau variabel dinyatakan reliabel jika memberikan nilai Cronbach Alpha > 0,60 .

\section{Analisis Regresi}

Analisis regresi, selain mengukur kekuatan hubungan antar dua variable atau lebih juga menunjukan hubungan antara variable dependen dengan variable independen (Ghozali, 2006). Analisis regresi linear berganda digunakan untuk mengetahui pengaruh dengan menentukan nilai Y (sebagai variabel dependen) dan untuk menaksirkan nilai-nilai yang berhunbungan denang $\mathrm{X}$ menggunakan rumus statistik:

$\mathrm{Y} 1=\mathrm{a} 1+\beta 1 \mathrm{X} 1+\beta 2 \mathrm{X} 2+\beta 3 \mathrm{X} 3+\mathrm{e}$

Keterangan :

a = konstanta

$\mathrm{Y}=$ Kinerja

$\mathrm{X} 1=$ Koefisien RegresiMotivasi

$\mathrm{X} 2=$ Koefisien Regresi Pelatihan

X3 = Koefisien Regresi Gaji

$\mathrm{e}=$ Galat/ Error 


\section{HASIL PENELITIAN}

$\underline{\text { Hasil Uji Validitas }}$

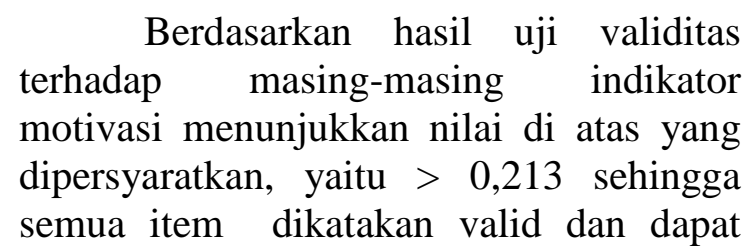
diproses dalam pegujian lanjutan.

Selanjutnya berdasarkan hasil uji validitas pelatihan terhadap masingmasing indikator pelatihan menunjukkan nilai yang dipersyaratkan, yaitu > 0,213, sehingga semua item dikatakan valid dan dapat diproses dalam pegujian lanjutan. Serta berdasarkan hasil uji validitas gaji terhadap masing- masing indikator menunjukkan bahwa terdapat indikator yang harus dikeluarjkan yaitu G1 dengan nilai korelasi pearson dibawah nilai korelasi yang dipersyaratkan, yaitu 0,000 < 0,213 ,

Selanjutnya berdasarkan hasil uji validitas kinerja terhadap masing-masing indikator menunjukkan bahwa terdapat indikator yang harus dikeluarkan yaitu K9 dengan nilai korelasi pearson dibahwah nilai korelasi yang dipersyaratkan, yaitu $0,104<0,213$, sehingga indikator tersebut dapat dihapuskan dan ketika uji selanjutnya tidak digunakan lagi. Sehingga indikator tersebut dapat dihapuskan dan ketika uji selanjutnya tidak digunakan lagi.

\section{$\underline{\text { Uji Reliabilitas }}$}

Berdasarkan hasil uji reliabilitas terhadap masing-masing indikator terdapat item pernyataan yang tidak memenuhi syarat reliabel. Dengan demikian, terdapat indikator yang dihapuskan yaitu M5, M6, M8, dan P6, P8 dengan nilai Cronbach's Alpha kurang dari 0,60 yang diprasyaratkan sehingga indikator tersebut dapat dikeluarkan dan ketika uji selanjutnya tidak digunakan lagi.
Hipotesis 1: Motivasi berpengaruh positif dan signifikan terhadap kinerja

Hasil uji hipotesis menunjukkan bahwa hubungan tersebut memiliki nilai $\beta$ 0.010 dan thitung sebesar 1.845 signifikan pada $\mathrm{a}=0,05$ (one tailed) nilai t-tabel 1,670. Nilai thitung $>$ tabel.

Hal tersebut menunjukan bahwa motivasi berpengaruh positif terhadap kineja. Dengan demikian dapat disimpulkan bahwa hipotesis 1 diterima. Hasil penelitian ini sesuai dengan penelitian yang dilakukan oleh Fauziah (2013).

Hipotesis 2: Pelatihan berpengaruh positif tetapi tidak signifikan terhadap kinerja

Hasil uji hipotesis menunjukkan bahwa hubungan tersebut memiliki nilai $\beta$ 0.010 dan $t$ hitung sebesar 666 signifikan pada $\mathrm{a}=0,05$ (on tailed) nilai t-tabel 1.670. Nilai thitung < t-table. Hal tersebut menunjukkan pelatihan berpengaruh positif tetapi tidak signifikan terhadap kinerja karyawan. Dengan demikian dapat disimpulkan bahwa hipotesis 2 tidak terdukung. Hasil penelitian ini sesuai dengan penelitian yang dilakukan oleh Riri dan Anita (2016).

Hipotesis 3 : Gaji berpengaruh positif tetapi tidak signifikan terhadap kinerja

Hasil uji hipotesis menunjukkan bahwa hubungan tersebut memiliki nilai $\beta$ 0.010 dan $t$ hitung sebesar 406 signifikan pada $\mathrm{a}=0,05$ (on tailed) nilai t-tabel 1.670. Nilai thitung < t-table. Hal tersebut menunjukkan gaji berpengaruh positif tetapi tidak signifikan terhadap kinerja karyawan. Dengan demikian dapat disimpulkan bahwa hipotesis 3 tidak terdukung. Hasil penelitian ini sesuai dengan penelitian yang dilakukan oleh Ikhwan (2017). 


\section{KESIMPULAN}

Berdasarkan hasil penelitian dan pembahasan hasil pengujian hipotesis atas pertanyaan-pertanyaan penelitian maka dapat diambil kesimpulan sebagai berikut:

1. Motivasi berpengaruh terhadap kinerja karyawan di Universitas Borneo Tarakan. Salah satu indikator motivasi yaitu situasi lingkungan kerja yang baik dan menyenangkan.

2. Pelatihan tidak berpengaruh terhadap kinerja karyawan. Tingkat ketepatan metode pelatihan yang digunakan dengan penyampaiaan materi masih kurang baik sehingga pelatihan tidak terlalu berpengaruh terhadap kinerja karyawan tetap di Universitas Borneo Tarakan.

3. Gaji tidak berpengaruh terhadap kinerja karyawan. Artinya semakin adil dan layak dan gaji yang diberikan tidak semakin tinggi maupun semakin rendahnya gaji kinerja karyawan.

\section{SARAN}

Berdasarkan hasil dan kesimpulan dalam penelitian ini, berikut adalah beberapa saran yang dapat penulis sampaikan:

1. Bagi peneliti selanjutnya yang akan mengambil judul penelitian yang sama sebaiknya menggunakan metode yang berbeda dan mengembangkan variabel untuk memperkuat pengaruh atau hubungan atara variabel dependen dan variabel independen yang ada pad penelitan ini.

2. Bagi Universitas Borneo Tarakan diharapkan dapat meningkatkan motivasi dan mengoptimalkna pelatihan dan gaji dalam bentuk apresiasi yang tinggi kepada kepada para karyawan.

\section{DAFTAR PUSTAKA}

Andrew E. Sikula. 2011. Manajemen Sumber Daya Manusia. Bandung: Erlangga.

Anita, Silvianita dan Ainun Mardiah Harahap, Riri.2016. Pengaruh Pelatihan Terhadap Kinerja Karyawan PT Pos Indonesia (Persero) Regional $V$. Bandung

Arikunto, Suharsimi. 2006, Prosedur Penelitian. Jakarta : Rineka Cipta.

Dessler, Gary. 2010. Manajemen Sumber Daya Manusia (edisi kesepuluh). Jakarta Barat: PT Indeks

Fauziah, Lia. 2013. Pengaruh Motivasi, Pelatihan Dan Kompensasi Terhadap Prima Semarang. Semarang. Semarang: Universitas Dian Nuswantoro.

Ferdinand, Augusty. 2006. Metode Penelitian Manajemen: Pedoman Penelitian untuk skripsi, Tesis dan Disertai Ilmu Manajemen. Semarang: Universitas Diponegoro.

Ghozali, Imam. 2006. Aplikasi Analisis Multivariate dengan Program SPSS Edisi Ke 4. Semarang: Badan Penerbit Universitas Diponegoro.

Hasan, M. Iqbal. 2003. Pokok-Pokok Materi Statistik 1(Statistik Deskriptif). Edisi Kedua, Penerbit. Jakarta: PT. Bumi Aksara.

Hasibuan, Malayu S.P 2007, Manajemen Sumber Daya Manusia Perusahaan. Bandung: PT. Bumi Aksa.

Ikhwan Maulana Haeruddin, M. 2017. Pengaruh Gaji dan insentif terhadap kinerja karyawan dan Organisational Citizenship Behaviour (OCB) pada Hotel Grand Clarion di Makassar. Makasar

Jackson. J.H. \& Mathis, R.L. 2006. Human Resource Management: Manajemen Sumber Daya 
Manusia. Terjemahan Dian Angelia. Jakarta: Salemba Empat.

Kaswan. 2012. Manajemen Sumber Daya Manusia untuk Keunggulan Bersaing Organisasi.Yogyakarta: Graha Ilmu.

Mangkunegara, A.A. Anwar Prabu. 2011. Manajemen Sumber Daya Perusahaan. PT . Remaja Rosdakarya. Bandung.

Mondy R Wayne. 2008. Manajemen Sumber Daya Manusia. Jakarta: Erlangga.

Musafir. 2009. Pengaruh Pelatihan dan Motivasi Terhadap Kinerja Pegawai Pelabuhan Indonesia IV Gorontalo. Jurnal Ichsan Gorontal, 4(2), 2371-2385.

Rezita, Riza. 2015. Pengaruh Latar Belakang Diklat terhadap kinerja pegawai pada Badan Perpustakaan dan Arsip Daerah Daerah Istimewa Yogyakarta. Yogyakarta

Rivai, Veithzal. 2009. Manajemen Sumber Daya Manusia Untuk Perusahaan Dari Teori ke Praktik. Jakarta: Raja Grafindo Persada.

Samsudin, alid. 2010. Sumber Daya Manusia. Bandung: Pustaka Setia.

Santika,E. 2011. Mengintip Kisah Dibalik Tembakau. Nasionalis Rakyat Merdeka news.

Sekaran, Umar. 2006. Metode Penelitian Untuk Bisnis 1. (4th ed). Jakarta: Salemba Empat.

Simamora, Binson. 2004. Panduan Riset Perilaku Konsumen. Jakarta: PT Gramedia Pustaka Utama.

Siti Mariah. 2013. Pengaruh Motivasi dan Kinerja Pegawai terhadap Kualitas Layanan Administrasi Akademik. Jurnal adminisistrasi Pendidikan Vol.XII No.1.

Soedjadi.2000. Kiat Pendidikan Matematika di Indonesia. Jakarta: Direktorat Jendral Pendidikan Tinggi Departemen Pendidikan Nasional.
Sopiah dan Sangaji, Etta Mamang. 2010.Metodologi Penelitian”. Yogyakarta: ANDI.

Sunyoto, Danang. 2013. Metodologi Penelitian Akuntansi. Bandung: PT Refika Aditama Anggota Ikapi.

Sugiyono. 2011. Metode Penelitian Kuantitatif, Kualitatif dan $R \& D$. Bandung: Afabeta.

Sugiyono.2012. Memahami Penelitian Kuantitatif. Bandung: Alfabeta.

Wibowo. 2007. Manajemen Kinerja. PT. Raja Grafindo Parsada: Jakarta. Wirawan. 2009. Evaluasi Kinerja Sumber Daya Manusia Teori Aplikasi dan Penelitian. Jakarta: Salemba Empat. 